Meta

Journal des traducteurs

Translators' Journal

\title{
Life is a Caravanserai: Translating Translated Marginality, a Turkish-German Zwittertext in English
}

\section{Luise von Flotow}

Volume 45, numéro 1, avril 2000

La traduction littéraire au Canada

Literary Translation in Canada

URI : https://id.erudit.org/iderudit/004578ar

DOI : https://doi.org/10.7202/004578ar

Aller au sommaire du numéro

Éditeur(s)

Les Presses de l'Université de Montréal

ISSN

0026-0452 (imprimé)

1492-1421 (numérique)

Découvrir la revue

Citer cet article

von Flotow, L. (2000). Life is a Caravanserai: Translating Translated Marginality, a Turkish-German Zwittertext in English. Meta, 45(1), 65-72. https://doi.org/10.7202/004578ar
Résumé de l'article

L'auteur d'ascendance turque Özdamar, dont le deuxième roman, écrit en allemand, s'intitule Das Leben ist eine Karawanserai (1992), a obtenu des prix littéraires allemands. Le lieu de l'action du roman, les personnages, les proverbes et les rites religieux et culturels sont turcs; il en est de même pour la structure des phrases, les jeux de mots et les images. Traduire de l'allemand a consisté à traduire une traduction. 


\title{
Life Is a Caravanserai: Translating Translated Marginality, a Turkish-German Zwittertext ${ }^{1}$ in English
}

\author{
LUISE VON FLOTOW \\ University of Ottawa
}

\begin{abstract}
RÉSUMÉ
L'auteur d'ascendance turque Özdamar, dont le deuxième roman, écrit en allemand, s'intitule Das Leben ist eine Karawanserai (1992), a obtenu des prix littéraires allemands. Le lieu de l'action du roman, les personnages, les proverbes et les rites religieux et culturels sont turcs; il en est de même pour la structure des phrases, les jeux de mots et les images. Traduire de l'allemand a consisté à traduire une traduction.
\end{abstract}

\begin{abstract}
Özdamar, an author of Turkish background, has written her second novel Das Leben ist eine Karawanserai (1992) in German and won prizes for German literature. The setting of the novel, the characters, the proverbs, the religious and cultural practices, the political problems are Turkish, as well as her sentence structure, wordplays and images. Translating her German has meant translating a translation.
\end{abstract}

\section{MOTS-CLÉS/KEYWORDS}

German literature, Emine Sevgi Özdamar, novel, literary translation, minority

In 1992 an energetic and unruly book entitled Das Leben ist eine Karawanserai hat zwei Türen aus einer kam ich rein aus der andren ging ich raus by Emine Sevgi Özdamar, a Turkish writer, made the literary headlines in Germany when its author won the prestigious Ingeborg Bachmann prize for German literature. While a prize for German language literature by non-Germans exists (the Chamisso prize), this writer competed with and won over German competitors. The result was greeted with derision by some German critics and with real interest and enthusiasm by others $^{2}$ : an understandable controversy since, on the one hand, the book is written in 'broken German,' a kind of Turkish-German dialect, and ignores many of the stylistic conventions of literary German, while on the other it tells the story of a child growing up in the 1950s and 60s in Turkey, and energizes its evocation of daily life with fragments of Turkish myths, folktales, prayers, proverbs, and poetry, as well as an array of strong women characters.

Emine Sevgi Özdamar is one of an increasingly vocal and successful number of 'minority' writers in Germany, writers who may have come as Gastarbeiter (labourers), or are second generation descendants of the first migrants. She is an actor, playwright and dramaturge and, most recently a novelist, publishing Mutterzunge (1990) (tr. by Craig Thomas, Mother Tongue, Toronto, Coach House, 1994), Das Leben ist eine Karawanserai... (1992) and Die Brücke am Goldenen Horn (1997). Contrary to earlier Gastarbeiterliteratur (literature by guestworkers) which thematized the difficulties of displacement, cultural loss and exclusion from the host country that the 
migrant experience entails, Özdamar's writing in Karawanserai focusses on Turkey. Through the eyes of a naive yet observant child-narrator, it describes life in an economically and politically uncertain environment where forces of Westernization, notably Americanization, are gaining influence over more traditional ways of life, and where, at the end of the book, emigration is the best option for the 17-year-old narrator. Thus, instead of thematizing the difficulties of adaptation to a new and sometimes hostile environment, or exploiting the topos of the abused or confined Turkish woman which has been a staple of cinema and popular writing by certain Turkish authors in Germany, ${ }^{3}$ Özdamar focusses on the source culture, and some of its troubles. Her descriptions of daily life in a family of six, constantly on the verge of, or in, bankruptcy and constantly in search of new lives in different parts of the country, provide fascinating and lively insights into another culture, while her unsentimental view of life in Turkey, her powerful and subversive women characters, and her inventive use of language and myth achieves what earlier works by migrant workers haven't: she avoids a confrontational stance vis-à-vis Germany, as well as clichéd, folklorish elements with regard to Turkey. In the view of Gino Chiellino, another migrant writer from Italy, one of the greatest challenges for the marginalized foreign writer in Germany is to not succumb to the stereotype expected of him or her. ${ }^{4}$ Only by refusing to play the role of the foreigner, the exotic outsider, can the foreign writer assert his or her place within German letters. With the award of the coveted Bachmann prize (and with her success in the theatre), Özdamar appears to have done just that.

\section{Karawanserai as 'Minority Literature'}

The book may not exploit clichés of Turkish-German 'minority literature,' but it constantly engages and plays with issues of marginality and minority which I would like to discuss with reference to a recent number of The Translator devoted to the theme of minority and translation. In the introduction, Lawrence Venuti develops three characteristics of minority literature. Citing Gilles Deleuze and Félix Guattari, he writes, "A 'minor literature,' they say, is characterized by three features: the "deterritorialization of language, the connection of the individual to a political immediacy, and the collective assemblage of enunciation" (Venuti 1998: 136). The work of many migrant writers in Germany seems to fit into this schematics of minority, but Özdamar is one of the first to truly revel in it, and in some ways, subvert this categorization.

A collective assemblage of enunciation: Karawanserai is very much concerned with language as an expression of a minority collectivity, as the book is written in the "Halbsprache" that the meeting of Turkish and German has brought forth. This language appears in an attenuated form in the novel, yet is still strange and disconcerting in what purports to be a German text; a good example is the title of the book, which consists of sentence fragments ("hat zwei Türen," tr. "has two doors"), idiosyncratic use of prepositions ("aus einer kam ich rein," tr. "out of one I came in") and elements of contracted spoken German ("kam ich rein / ging ich raus," tr. I came in/ I went out). This language use affirms a certain collectivity of Turkish expression in Germany, and represents speakers of this 'broken' German, thus also evoking the history of their domination and marginalization. Indeed, Deniz Göktürk, herself a 
Germanist of Turkish background, cites Özdamar as saying “The mistakes are my identity. Five million people who live here speak with these mistakes. This is a new language" (my translation, Göktürk 1994: 81). Paradoxically though, the content of the novel moves away from this minority collectivity, and delves into the very different lives and attitudes of Turks living in Turkey. The Turkish setting reveals how heterogeneous Turkish society is, dispelling perceptions Germans may have of Turks as a homogeneous group, while the language of the text confronts German readers with a 'broken' German that resonates with the language their Turkish neighbours use.

Political immediacy: There is a clear political immediacy in writing in 'broken' German and thereby representing a minority/migrant population. Much of this type of 'minority' writing has previously signalled attempts to make room for other voices in Germany, and give voice to the concerns and experiences of outsiders, often as a kind of "therapeutic writing by victims of social processes" ${ }^{6}$ which thematizes their minority status. Özdamar both uses and undermines this topos. By writing in TurkishGerman she represents the minority group, but by setting her work in the country of origin she moves this group into a majority position. The Germans are the ones who are marginally present - as occasional hapless tourists or as labour recruiting agents easily duped by Turkish job applicants. The text is both a politically immediate act and a playful attenuation of the act.

Deterritorialization: Deleuze and Guattari use the term deterritorialization for the effect minority writing has "as crystals of becoming whose value is to trigger uncontrollable movements and deterritorializations of the mean or majority" (Venuti 1998: 139). The principle is most evident in Özdamar's direct translations from Turkish. By taking concepts, names, expressions and syntactic structures from the minority language Turkish and translating them literally into German, she systematically deterritorializes German, producing a German that is understandable but not grounded in German culture-it has been moved out of its territory. A good example is the title of her first publication, Mutterzunge. This is a literal translation from Turkish "ana dil," the literal equivalent of the English "mother tongue." Yet in German, "tongue" or "Zunge" refers only to the tongue in your mouth and not to the language you speak, so that the image produced by the title is the disconcerting one of a mother's tongue (Göktürk 1994: 80). Mutterzunge, in fact, says "mother's tongue." In addition to deterritorializing German, Özdamar conceals Turkish within the German she writes, producing a subtext through literal translation that is only available to readers/speakers of Turkish. Example: the best friend of the narrator's mother, the woman who puts the sixteen-year-old on the train to her father shortly before the narrator's birth, is referred to throughout as "Baumwolltante." There is no explanation for this strange name, which translates into English as "Cotton Aunt." Only a Turkish reader can translate back into Turkish and get the joke: "Baumwolltante" translates a colloquial Turkish term for the madame of a whorehouse. ${ }^{7}$ The irony that this old friend of the family is lovingly called a madame must escape most German and English readers, and so must much of the other wordplay based on literal translation.

Karawanserai thus often seems to locate itself on both sides of the minority/ majority divide, tending toward the Turkish-as-majority-culture, through its Turkish setting, the citations of long Arabic prayers transliterated into Turkish, Turkish poetry, myths and language fragments throughout the text, yet it also functions 
within the 'minority' rubric with its use of 'broken' German as the vehicle for writing the text. Asked why the foreign sound is maintained in German, Özdamar's response emphasized the process of acquiring a new language: "I was [...] very keen [...] to retain some 'mistakes' in the book's language. Readers must be able to experience for themselves the process the writer has gone through linguistically. They have to be made to stumble, as it were" (Horrocks and Kolinski 1996: 49). "Experiencing the process" doubtless implies the slow and tedious movement from wordlessness to literary creation in a new language and culture; and the "stumbling" doubtless occurs when readers are confronted with the idiosyncratic language and imagery that literal translation from Turkish inevitably provides. Yet this literalness also has a purging effect, as Özdamar discusses with Horrocks and Kolinski. She describes first becoming interested in this form of German on train journeys between Berlin and Turkey, when German was the lingua franca of a very mixed set of travellers-Bulgarians, Yugoslavs, Turks - who spent the time together telling each other stories from their own cultures. "They made mistakes, of course, but the German they spoke was devoid of clichés, and came out almost like poetry as they struggled to express the images of their mother tongues in this new language" (Horrocks and Kolinsky 1996: 47). Through literal translation, then, the new, 'métisse' language ${ }^{8}$ has been cleansed of tired clichés and everyday conversations sound "almost like poetry."

\section{Translating a 'Minority' Zwittertext}

Özdamar's 'broken' German presents the greatest challenge in translating Karawanserai into English. Preserving or rendering this foreigness seems to be desirable, since it is an integral part of the source text. Reproducing it as effectively as possible in English may even contribute to the translation having a certain 'political immediacy,' although Turkish-German issues are not Turkish-English issues: several million Turks have not gone through the process of learning and adapting to English. The 'information load's carried by the use of 'broken' German may thus be somewhat diluted, so that the text in English resonates simply as '(im)migrant' writing. Still, to produce some form of 'broken' English is to maintain the foreign aspects of the source. Its effect is contrary to translating Mutterzunge as Mothertongue, where a disconcerting, unexpected image in German is replaced with a conventional term in English.

The solution seems to be to translate as literally as possible, to deliberately build irregularities into the English version and write "angular English"10 that will somehow match or replicate elements critic Göktürk has described as "ungelenk” (clumsy) (1994: 82) in the source text. Literal English translation of the literal German translations from Turkish may even allow English readers/speakers of Turkish to understand and enjoy some of the subtext of hidden wordplay. Other readers will simply have access to 'broken' language as one of the most important stylistic features of the book, the feature that locates it in a 'minority' culture.

In what follows, I will discuss a few examples of translation problems related to Özdamar's idiosyncratic German. These concern language register, imagery, syntactic disruption, obscenities and the use of Turkish/Arabic terms and expressions.

Language Register: The narrator of Karawanserai is a young girl. Her language is childlike, with simple SVO sentence structures, childish expressions, and repetitions. 
While this is doubtless a deliberate stylistic device, it is also the language of someone learning German, someone who has not mastered the complexities of subordination or differences in register. These simple structures are much easier to transfer into English than the convolutions of more conventional literary German. The effect of the translation is, however, quite different. The language of the translation becomes less childlike (since the gap between this language and high literary style is less marked in English), and instead takes on a curiously clipped military tone-which may be oddly appropriate in another sense: the military is omnipresent in 1950s and 60s Turkey:

Our new street was called mausoleum street. My mother said, “Today we're going up to see Atatuerk. Grandmother, get dressed up." Both women put on their good clothes, Grandfather went to the barber for a shave and had my brothers' hair cut. Only then did we go up the steep path at the end of our mausoleum street. The first thing we saw when we got to the top were the soldiers. Two columns and a soldier between them, another two columns and a soldier between them, then another two columns and a soldier between them. Grandfather said, "This building was built by a heretic, it is a heartless building.

The short sentences with SVO structure are evident in this piece, as is the repetition- "two columns with a soldier," etc. Comma splices, another recurring element, reproduce the oral nature of the language used here and emphasize its childlike qualities. Finally, the abrupt tone of the conversation, "Grandmother, get dressed up," may indicate a learner's unfamiliarity with German expressions of politeness. A gentler version might read "Grossmutter, zieh dir doch bitte deine besten Kleider an," a less agressive imperative than the command the grandmother is issued here.

Obscenities: Curious obscenities proliferate in the text. This is doubtless an aspect of language register, but also raises questions about cultural differences revealed through literal translation. The girl narrator, for example, recounts that her mother often chastises the children for making a mess in the house. The mother says, "Cocuklar, Kinder, ihr habt das Haus gefickt" (184) (tr. Cocuklar, children, you've fucked the house"). The German term is a rarely used obscenity that communicates anger and agression; for a German reader it is more than strange to hear a mother using it to scold her children. The English translation does not provide quite as unusual a register of language: the term "fucked up" and its many variations have largely entered the language, though they may not be used by many mothers of small children. Translating the expression literally here, and not respecting contemporary English usage "fucked-up," enhances the foreign feel of the text. A similar situation arises when the old gravedigger helps the narrator's grandmother out of the newly dug grave from which she has rescued the baby which is believed to be dying: he says "Hier, nimm meine Hand, ich ficke meine Hand, ich ficke deine Enkelin, ich ficke das Grab" (15) (tr. "Here, take my hand, I fuck my hand, I fuck your granddaughter, I fuck the grave"). Not only is the vulgarity most unusual in German and in English, but its occurrence very early in the novel in some ways prepares readers for this type of language use. The translation uses the simple present in English, making the obscenity less immediate. A final example concerns the term used for women's genitalia: the girl's father returns home from a failed trip to the moneylenders and responds to the criticisms of his mother, who thinks he ought to do an honest day's labour. He tells her to be happy she has not yet been sent out to prostitute herself: 
Ich, der große Bauunternehmer. Mutter, misch dich nicht mit dem Teig an deiner Hand in Männersachen. Habe ich euch bis jetzt als Nutten arbeiten geschickt? Ich habe nicht geschickt. Ihr sitzt zu Haus, eine Hand über die andere, und die Hände über eurer Schachtel. (107)

tr. Me, the great building contractor. Mother, don't get involved in men's business when you have dough on your hand. Have I ever sent you to work as whores? I haven't sent. You sit at home, one hand over the other and both hands over your little boxes.

This response raises a translation problem around the word "Schachtel" used for women's genitals. Doubtless a literal translation from Turkish, it is surprising in German, which does not use the same slang. In German, "Schachtel" designates a small, thin-walled box made of cardboard or thin wood, as in a box of chocolates. English, however, does have the slang term "box." It is part of a rude, rough register that seems out of place for a son talking to his mother, or little girls talking to each other, or a mother to her daughter. Here, registers of language in Turkish and English clash: the Turkish "Schachtel" is used easily by many different people in the book, and though the English "box" exists, it carries an angrier misogynist tone. A possible solution is to translate "little box" as Horrocks and Kolinski do in their extracts from Karawanserai.

Grammar/Syntax: The citation above contains an example of the odd syntactic structures that signal 'broken' German. The father answers his rhetorical question about sending his wife and mother out to earn money as prostitutes by saying "Ich habe nicht geschickt." Normally, "schicken" requires a direct object in German; the 'broken' structure is easily maintained in 'I haven't sent'. Other reproducible features in English translation are the lack of articles, missing conjunctions and connectors, and idiosyncratic use of prepositions. In the German text, for instance, the girl is sent into a bar to find her father. She describes the men there sitting on the tables with their drinks; Turkish has a locative case and doesn't use prepositions to specify place, and Turkish speakers of German evidently have some difficulty choosing the right one.

Imagery: Perhaps the most colourful aspect of producing an English version of this Turkish-German Zwittertext involves the unexpected images the work presents. They remain as outlandish in English as they are in German. For example, the narrator falls ill with tuberculosis and is taken off to Bursa, a city renowned for its clean air; here she expects to get better soon: "Die Luft vom Heiligen Berg in Bursa wird meine wunden Lungen wie von einem heiligen großen Vogel geleckt wieder zumachen" (113, tr. "The air from the Holy Mountain of Bursa will close my sore lungs as though licked by a great holy bird.") Birds that heal wounds by licking them are not a staple of German or English mythical images. On a different note, the women of the narrator's family and neighbourhood are very interested in "Würmer ausschütteln" (tr. "shaking out their worms") and find all kinds of ways to do so. In this case the narrator explains, "Würmer ausschütteln bedeutete bummeln gehen, sich amüsieren" (114, tr. "Shaking out worms meant going for a walk, having fun"). Özdamar glosses the term here, but more often the images are not explained: the stone houses of Bursa are compared to dentures with the single wooden house as the rotten tooth that is left over; the richer women, who are isolated in the fine stone houses all day, look "als ob sie ständig in sich selbst regneten" (tr."as though they were continuously raining inside themselves"), and the soul of the street during the day is described "als 
wenn ein Mensch seine beiden Füße in einen einzigen Schuh reingesteckt hätte” (tr. "like a person who has both feet stuck into one shoe"). Outlandish and exotic as it is, this imagery has earned a certain amount of criticism from critics such as Göktürk who wonder whether Özdamar is not running the risk of subscribing to 'orientalist' clichés. Similar criticisms could doubtless be uttered with respect to a close English translation.

Turkish/Arabic terms: The text is studded with Turkish and transliterated Arabic expressions. These are everyday expressions such as "tamam mi" (tr. "OK”), children's games "seksek" (hopscotch), or snippets of conversation that are a part of family discussions, and on the other hand, Arabic prayers and religious expressions such as "Insallah" that accompany many of the activities of the day. Left in their original Turkish form in the English translation, they pose no difficulty for translation, functioning in similar ways in both German and English, consistently signalling the otherness of the source culture, the difference from which the newly 'broken' German/ English has been distilled.

Translating a 'minority' text into a 'majority' language is fraught with difficulties, the most important being the danger of erasing the marks that signal the status of the source text. It is interesting that in Karawanserai, the foreign or 'minority' elements in the work are, to a great extent, already a function of literal translation from Turkish. Here, translation into the dominant language does not erase difference; instead it enhances the difference that Özdamar focuses on by setting her text in Turkey and it undermines (deterritorializes) literary German at the same time. It seems clear that a similar approach for the English version will ensure retention of at least some of the 'minority' features of the text.

\section{NOTES}

1. This term refers to the hybrid nature of this writing. A literal translation is "hermaphrodite text."

2. The controversy is summarized briefly in "Muttikültürelle Zungenbrecher: Literatürken aus Deutschlands Nischen” by Deniz Göktürk.

3. Deniz Göktürk discusses this topos in her article "Kennzeichen: weiblich/ türkisch/ deutsch...Beruf: Sozialarbeiterin/ Schriftstellerin/ Schauspielerin."

4. Chiellino, Gino (1992): Fremde. A Discourse of the Foreign, tr. Luise von Flotow, Toronto, Guernica Editions.

5. This is a negatively connoted term for the mixture of German and Turkish spoken by first and second generation migrants. See "Turkish Everyday Culture in Germany" by H. F. Waldhoff in Turkish Culture in German Society Today, eds. David Horrocks and Eva Kolinsky.

6. See Sabine Fischer and Moray McGowan, "From Pappkoffer to Pluralism: On the Development of Migrant Writing in the German Federal Republic," Turkish Culture in German Society Today, eds. David Horrocks \& Eva Kolinsky, pp. 1-22.

7. Thanks to Ozlem Sensoy, participant at the 1998 meeting of the American Literary Translators' Association in Guadalajara and translator of Turkish and Kurdish literature, for this information.

8. See Alexis Nouss et François Laplantine, Le Métissage, for a measured discussion of the concept of métissage.

9. This term comes from Maria Tymoscko's work on the translation of marginalized texts. It refers to the amount of information contained in lesser known or ancient texts and carried in literary references, images, rhythms, etc., which constitutes an enormous challenge in translation.

10. One anonymous reader of the manuscript of the translation criticized the 'angular English' of the translation and wanted a smoother text. 


\section{REFERENCES}

Özdamar, Emine Sevgi (2000): Das Leben ist eine Karawanserai hat zwei Türen aus einer kam ich rein aus der andren ging ich raus, Köln, Kiepenheuer \& Witsch 1992. Tr. Luise von Flotow, Life Is A Caravanserai Has Two Doors I Came In One I Went Out The Other, London, Middlesex University Press.

— (1990, 1998, 1994): Mutterzunge, Berlin, Rotbuch Verlag 1990/Köln, Kiepenheuer \& Witsch 1998. Tr. Craig Thomas, Mothertongue, Toronto, Coach House Press, 1994.

\section{Secondary Literature}

GöKтÜRK, Deniz (1994): “Muttikültürelle Zungenbrecher: Literatütken aus Deutschland Nischen,” Sirene 12/13, pp. 77-92.

GÖKTÜRK, Deniz: "Kennzeichen: weiblich/ türkisch/ deutsch ... Beruf: Sozialarbeiterin/ Schriftstellerin/ Schauspielerin ...," Schrift Geschichte Geschlecht, eds. Renate Möhrmann und Hiltrud Gnüg, in press.

Horrocks, David and Eva Kolinsky, eds. (1996): Turkish Culture in German Society Today, Providence and Oxford, Berghahn Books.

Laplantine, François et Alexis Nouss (1997): Le Métissage, Paris, Flammarion.

MüLleR, Regula (1997): “”Ich war Mädchen, war ich Sultanin”: Weitgeöffnete Augen betrachten türkische Frauengeschichte(n)," Denn du tanzt auf einem Seil. Positionen deutschsprachiger MigrantInnenliteratur, Sabine Fischer und Moray McGowaneds, eds, Tübingen, Stauffenburg Verlag, pp. 133-149.

Tyмосzко, Maria (1995): “The Metonymics of Translating Marginalized Texts," Comparative Literature, Winter 1995, pp. 11-22.

Venuti, Lawrence (1998): "Introduction" to The Translator. Studies in Intercultural Communication, special issue on translation and minority, 4,2, pp. 135-144.

WierschKe, Annette (1997): "Auf den Schnittstellen kultureller Grenzen tanzend: Aysel Özakin und Emine Sevgi Özdamar," Denn du tanzt auf einem Seil. Positionen deutschsprachiger MigrantInnenliteratur, Sabine Fischer und Moray McGowan, eds., Tübingen, Staffenburg Verlag, pp. 179-194. 